\title{
HYPOTHETICAL LEARNING TRAJECTORY PESERTA DIDIK KELAS X SMA NEGERI 2 PALOPO PADA MATERI TRIGONOMETRI MELALUI MODEL PEMBELAJARAN KOOPERATIF TIPE GROUP INVESTIGATION
}

\author{
Aprila Stanis Prasetia ${ }^{1}$, Salwah $^{2}$, Karmila $^{3}$ \\ Program Studi Pendidikan Matematika, Fakultas Keguruan dan Ilmu Pendidikan, \\ Universitas Cokroaminoto Palopo \\ aprilastanis@gmail.com, salwah@uncp.com, karmila@uncp.com
}

\begin{abstract}
Abstrak
Penelitian ini bertujuan untuk mengetahui hypothetical learning trajectory peserta didik kelas X SMA Negeri 2 Palopo melalui model pembelajaran kooperatif tipe group investigation. Penelitian ini merupakan penelitian kualitatif dengan jenis penelitian deskriptif. Instrumen penelitian yang digunakan 1) peneliti, 2) lembar kerja peserta didik, 3) lembar observasi keterlaksanaan pembelajaran, 4) lembar observasi aktivitas peserta didik, dan 5) pedoman wawancara. Analisis data dilakukan dengan reduksi data, penyajian data dan penarikan kesimpulan. Pengecekan keabsahan data dilakukan dengan metode triangulasi. Hasil penelitian menunjukkan bahwa model pembelajaran kooperatif tipe group investigation mendukung untuk melihat hipotesis lintasan belajar peserta didik dan selain itu, alur berpikir peserta didik tidak jauh berbeda dengan hipotesis lintasan belajar yang dibuat oleh peneliti. Alur berpikir kelompok peserta didik aktif pada materi trigonometri, menunjukkan bahwa peserta didik dapat memahami dan menyelesaikan soal sesuai dengan prosedur pengerjaan soal walaupun ada sedikit kesalahan. Alur berpikir kelompok peserta didik sedang pada materi trigonometri, menunjukkan bahwa peserta didik dapat memahami dan mengerjakan soal walaupun masih mengalami kekeliruan dan masih terdapat jawaban yang kurang tepat. Adapun alur berpikir kelompok peserta didik tidak aktif pada materi trigonometri, menunjukkan bahwa peserta didik dapat menyelesaikan soal walaupun masih terdapat banyak kesalahan pada hasil jawabannya.

Kata kunci: Hypothetical Learning Trajectory, Model Pembelajaran Kooperatif Tipe Group Investigation, Trigonometri.
\end{abstract}

\section{A. Pendahuluan}

Menurut Hanafi (Nikmaturrohmah, 2018) matematika merupakan ilmu dengan objek kajian yang bersifat hirarkis, dimana masing-masing topik dalam matematika berururtan dan saling berkaitan. Materi matematika disusun secara bertahap mulai materi dasar hingga materi yang sulit. Semakin tinggi tingkatannya, maka semakin tinggi pula tingkat kesulitannya. Untuk itu, peserta didik dalam mempelajari materi matematika haruslah bertahap. Tahapan ini 
dibutuhkan agar peserta didik memiliki panduan untuk dapat belajar dan meningkatkan pemikirannya. Mengetahui tingkat berpikir peserta didik dapat membantu guru dalam mengetahui mana saja yang harus didahulukan dalam pembelajaran sehingga pembelajaran efektif di kelas dapat terwujud (Wuriyudani, 2015). Untuk itu, dalam merancang kegiatan pembelajaran guru harus mempunyai dugaan atau hipotesis untuk mempertimbangkan reaksi peserta didik. Dugaan yang dimaksud adalah hypothetical learning trajectory (HLT). HLT merupakan suatu dugaan atau hipotesis bagaimana pemikiran dan pemahaman peserta didik berkembang dalam aktivitas pembelajaran. HLT memberikan petunjuk bagi guru untuk menentukan dan merumuskan tujuan pembelajaran yang ingin dicapai, sehingga guru dapat membuat strategi atau langkah-langkah yang akan digunakan untuk mewujudkan tujuan pembelajaran yang diharapkan.

Guru memiliki tanggung jawab untuk mempersiapkan rancangan sajian bahan ajar yang diharapkan mampu mengatasi kesulitan yang dimiliki peserta didik dalam pembelajaran. Menurut Mhuzdaliva (2016) kesulitan yang dihadapi peserta didik pada materi trigonometri yaitu 1) trigonometri dianggap sebagai materi yang sulit, 2) peserta didik tidak mampu menguasai rumus-rumus trigonometri, dan 3) kesalahan peserta didik dalam merumuskan masalah pada soal uraian atau soal cerita karena konsep yang belum tepat. Kesulitan peserta didik dalam memahami materi trigonometri khususnya perbandingan trigonometri pada segitiga siku-siku disebabkan karena kurangnya pemahaman peserta didik terhadap konsep trigonometri (sinus, cosnius, tangen, secan, cosecan dan cotangen). Hal ini didukung oleh pernyataan menurut Al Krismanto (Ratnasari, 2018) yang menyatakan bahwa kenyataan di lapangan menunjukkan bahwa dalam kegiatan pembelajaran sering dijumpai kesulitan dalam memahami konsep trigonometri, dikarenakan penyajian rumus-rumus dijumpai secara instan sehingga pembelajaran menjadi kurang bermakna.

Mengatasi kesulitan yang dihadapi peserta didik, guru perlu menyiapkan sebuah desain pembelajaran yang mendukung peserta didik untuk mencapai tujuan pembelajaran. Membuat desain pembelajaran, guru membutuhkan hypothetical learning trajectory atau biasa diartikan sebagai dugaan lintasan belajar yang akan dilalui peserta didik selama aktivitas pembelajaran berlangsung 
untuk mempermudah peserta didik dalam memahami materi yang diajarkan. Dugaan tersebut terkait dengan bagaimana kemampuan peserta didik berkembang selama aktivitas belajar yang didesain guru. Hal ini terlihat pada pemikiran dan perencanaan yang terjadi selama proses pembelajaran, termasuk respon spontan yang dibuat dalam menanggapi pemikiran peserta didik. Hypothetical learning trajectory yang disiapkan guru ini didukung oleh model pembelajaran kooperatif tipe group investigation, di mana group investigation merupakan model pembelajaran berkelompok yang mengharuskan peserta didik terlibat secara aktif dan melatih peserta didik untuk menumbuhkan kemampuan berpikir mandiri terkait masalah yang dihadapi dan bagaimana mereka menyelesaikan masalah tersebut dengan berkerja sama secara berkelompok. Model pembelajaran group investigation ini diharapkan dapat mempermudah jalannya pembelajaran agar hypothetical learning trajectory peserta didik lebih mudah untuk digambarkan.

Berdasarkan uraian di atas, penulis terdorong untuk melakukan kajian secara lebih spesifik mengenai "Hypothetical Learning Trajectory Peserta Didik Kelas X SMA Negeri 2 Palopo pada Materi Trigonometri Melalui Model Pembelajaran Kooperatif tipe Group Investigation".

\section{B. Metode Penelitian}

Penelitian ini adalah penelitian kualitatif dengan jenis penelitian deskriptif yang bertujuan untuk menggambarkan HLT peserta didik pada materi perbandingan trigonometri pada segitiga siku-siku melalui model pembelajaran kooperatif tipe group investigation. Penelitian ini dilaksanakan di kelas X IPA 1 SMA Negeri 2 Palopo pada semester genap tahun ajaran 2019/2020. Subjek penelitian ini adalah subjek kelompok peserta didik aktif (SKA), subjek kelompok peserta didik sedang (SKS) dan subjek kelompok peserta didik tidak aktif (SKTA). Instrumen penelitian ini yaitu instrumen utama (peneliti sendiri) dan instrumen pendukung (lembar kerja peserta didik, lembar observasi keterlaksanaan pembelajaran, lembar observasi aktivitas peserta didik dan pedoman wawancara. Penelitian ini dilakukan untuk satu kali pertemuan. Data penelitian diperoleh melalui observasi pembelajaran untuk penentuan subjek penelitian, lembar kerja peserta didik digunakan untuk mendapatkan informasi mengenai HLT subjek penelitian, dan lembar observasi aktivitas dan wawancara digunakan untuk memverifikasi ataupun mendapatkan 
data tambahan dari HLT subjek penelitian sedangkan, data hasil observasi keterlaksanaan model pembelajaran digunakan untuk melihat seberapa baik keterlaksanaan model pembelajaran diterapkan pada satu kali pertemuan untuk melihat HLT subjek penelitian. Data yang terkumpul dilanjutkan dengan proses analisis dan validasi melalui triangulasi metode. Teknik analisis data dilakukan dengan model Miles dan Hiberman yaitu (Data Reduction, Data Display dan Conclusion).

\section{Hasil Penelitian Dan Pembahasan}

Hypothetical learning trajectory (HLT) merupakan gambaran proses pembelajaran yang dilalui peserta didik dari kegiatan awal sampai akhir pembelajaran berlangsung. Menurut Sholihah (2018) istilah HLT merujuk pada rencana guru berdasarkan antisipasi belajar peserta didik yang mungkin dicapai dalam pembelajaran yang didasari oleh tujuan pembelajaran matematika. Sejalan dengan lintasan belajar, menurut Simon (Fuadiah, 2017) guru hendaknya menyusun rencana pembelajaran yang sesuai dengan lintasan belajar peserta didik. Menurut Fuadiah (2017) fungsi utama dari rencana pembelajaran sendiri adalah untuk memberikan peserta didik kesempatan belajar sehingga guru harus merencanakan apa yang mungkin terjadi selama proses pembelajaran. Rencana pembelajaran ini juga berhubungan dengan bagaimana guru memilih model pembelajaran yang sesuai untuk diterapkan pada pembelajaran.

Pemilihan model pembelajaran menjadi faktor penting yang perlu dipertimbangkan agar pembelajaran sesuai dengan yang diharapkan. Adanya model pembelajaran dapat menciptakan suasana belajar yang berbeda dan menjadi lebih menarik dari biasanya. Salah satu model pembelajaran yaitu model pembelajaran kooperatif tipe group investigation yang berpusat pada peserta didik dan pada kelompok kecil yang heterogen untuk melakukan investigasi. Model pembelajaran ini dapat melatih peserta didik dalam mengembangkan kemampuannya serta melatih keterlibatan peserta didik dalam kelompok maupun pada saat pembelajaran di kelas. Selain itu, model pembelajaran ini menuntut agar peserta didik aktif berdiskusi dan aktif dalam mencari atau menginvestigasi materi atau permasalahan yang diberikan. 
Model pembelajaran kooperatif tipe group investigation ini dipilih agar peneliti dapat melihat HLT dari subjek penelitian pada saat menyelesaikan lembar kerja. HLT atau dugaan lintasan belajar dalam penelitian ini yaitu pada SKA, SKS, dan SKTA. SKA, SKS maupun SKTA memiliki alur berpikir yang tidak jauh berbeda dengan HLT yang dibuat oleh peneliti yaitu memahami konsep perbandingan trigonometri pada segitiga siku-siku, menentukan perbandingan trigonometri pada segitiga siku-siku, menentukan hubungan antar perbandingan trigonometri pada segitiga siku-siku, dan menyelesaikan masalah nyata yang berkaitan dengan perbandingan trigonometri pada segitiga siku-siku. Melihat data keterlaksanaan model pembelajaran yang dilaksanakan peneliti, menunjukkan bahwa model pembelajaran ini mendukung peneliti untuk melihat HLT peserta didik. Tahap yang mendukung peneliti untuk melihat HLT yaitu pada tahap penyelidikan (investigation). Tahap penyelidikan ini membagikan lembar kerja pada subjek penelitian, dimana lembar kerja ini telah disesuaikan dengan HLT peneliti. Hasil lembar kerja yang diperoleh dari subjek penelitian inilah yang kemudian dibandingkan dengan HLT peneliti dengan HLT yang sebenarnya yang dilalui oleh subjek penelitian, sehingga diperoleh HLT subjek penelitian yang direvisi berdasarkan aktivitas yang dilakukan.

Hasil jawaban SKA menunjukkan bahwa SKA dapat mengerjakan soal, dimana SKA dapat menyelesaikan tiga dari empat soal dengan benar. Adapun alur berpikir SKA, yaitu dapat menyelesaikan soal terkait perbandingan trigonometri pada segitiga siku-siku walaupun masih terdapat sedikit kesalahan pada saat menemukan perbandingan dari segitiga siku-siku $P Q R$. Sehingga, dari keempat nomor soal, SKA hanya mengalami kesalahan pada nomor 1 sedangkan untuk soal lainnya SKA tidak mengalami kesalahan. 


\section{Berikut paparan hasil jawaban dan wawancara SKA :}

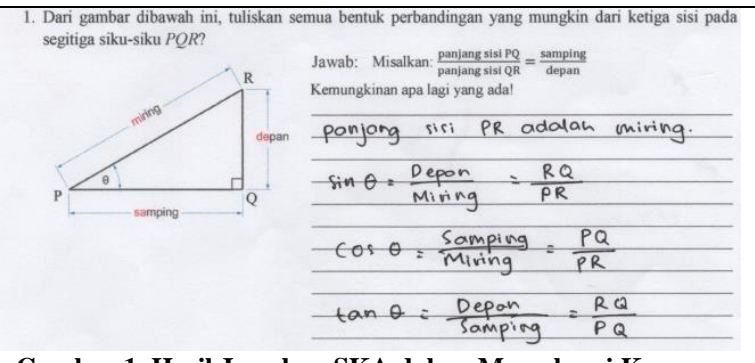

Gambar 1. Hasil Jawaban SKA dalam Memahami Konsep Perbandingan Trigonometri pada Segitiga Siku-siku
SKA dapat memahami perbandingan trigonometri pada segitiga siku-siku dengan menuliskan konsep perbandingan yang ditemukan. SKA menuliskan 3 konsep perbandingan yaitu perbandingan sinus, cosinus dan tangen. Jawaban SKA sudah benar dalam menuliskan perbandingan yang mungkin terbentuk dari segitiga $P Q R$, namun jawaban SKA masih kurang lengkap. Berikut wawancara yang dilakukan dengan SKA :

- SKA-02 (P) : untuk soal nomor 1, bagaimana tahapan kalian dalam menyelesaikan soal tersebut?

- SKA-02-2 (J) : pertama itu, kami lihat dari segitiga $P Q R$, dimana perbandingan yang ditemukan itu ada 3

- SKA-03 (P) : jadi perbandingannya cuman ada 3 ?

- SKA-03-6 (J) : dari segitiga $P Q R$ bias terbentuk 6 perbandingan tapi kami fokusnya 3 perbandingan saja

- SKA-03-5 (J) : iya, karena menurut kami, 3 perbandingan itu adalah perbandingan utama dan sisanya itu hubungan yang nanti terbentuk dari 3 perbandingan sebelumnya

- SKA-04 (P) : bagaimana bentuk konsep perbandingan yang kalian temukan pada soal?

- SKA-04-2 (J) : konsep yang kami temukan itu ada 3, sinus itu depan/miring, cosinus itu samping/miring dan tangen, depan/samping.

\begin{tabular}{|c|c|c|c|}
\hline $\begin{array}{c}\text { Tujuan } \\
\text { Pembelajaran } \\
\text { (learning goal) }\end{array}$ & $\begin{array}{c}\text { Aktivitas } \\
\text { Pembelajaran } \\
\text { (learning activity) }\end{array}$ & $\begin{array}{c}\text { Dugaan Alur Berpikir Peserta } \\
\text { Didik (hypothetical learning } \\
\text { process) }\end{array}$ & $\begin{array}{c}\text { Bantuan Guru (teacher } \\
\text { support) }\end{array}$ \\
\hline $\begin{array}{l}\text { Memahami } \\
\text { konsep } \\
\text { perbandingan } \\
\text { trigonometri } \\
\text { pada segitiga } \\
\text { siku-siku }\end{array}$ & $\begin{array}{l}\text { Peserta didik } \\
\text { mengerjakan soal } \\
\text { mengenai konsep } \\
\text { perbandingan } \\
\text { trigonometri pada } \\
\text { segitiga siku-siku. } \\
\text { Dalam hal ini soal } \\
\text { nomor } 1 \text {. }\end{array}$ & $\begin{array}{l}\text { Tipe } 2 \\
\text { Peserta didik dapat menentukan } \\
\text { bentuk perbandingan yang } \\
\text { mungkin pada segitiga siku-siku } \\
P Q R \text {. Namun, dalam hal ini } \\
\text { masih terdapat penulisan } \\
\text { jawaban yang masih kurang } \\
\text { tepat }\end{array}$ & $\begin{array}{l}\text { Tipe } 2 \\
\text { Untuk jawaban peserta } \\
\text { didik tipe } 2 \text {, guru } \\
\text { memberikan bantuan } \\
\text { dengan mengingatkan } \\
\text { bahwa terdapat } 6 \\
\text { perbandingan yang } \\
\text { terbentuk dari segitiga } \\
P O R \text {. }\end{array}$ \\
\hline
\end{tabular}

HLT SKA dalam Memahami Konsep Perbandingan Trigonometri

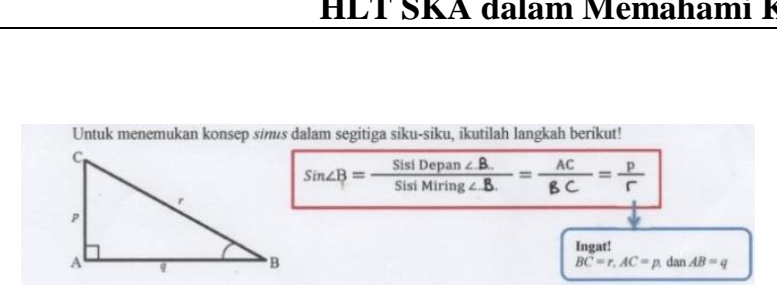

Berdasarkan keterangan di atas, maka yang dimaksud $\operatorname{Sin} \angle B$ adalah perbandingan Sisi depan $\angle B$ dan sisimining $\angle B$, atar sisi $A C$ dan sisi $B C$

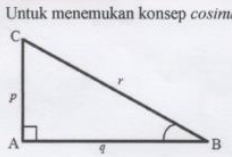

lam segitiga siku-siku, ikutilah langkah beriku!

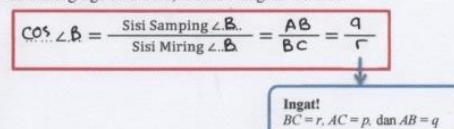

Berdasarkan keterangan di atas, maka yang dimaksud $\cos \angle B$ adalah perbondingon antora sisi samping iudut $B$ dengan sisi miving sudut $B$, atou Sisi $A B$ dengan sisi $B C$

Untuk menemukan konsep tangen dalam segitiga siku-siku, ikutilah langkah berikut!
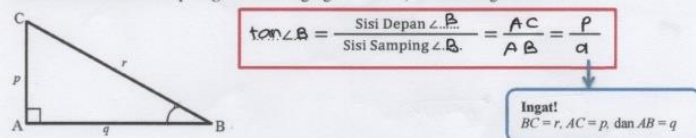

Berdasarkan keterangan di atas, maka yang dimaksud $\operatorname{Tan} \angle B$ adalah perbandingan $\mathrm{Sis}$ depan $\angle B$ dengan sis samping $\angle B$, atau sisi $A C$ dengan Sisi $A B$

Gambar 2. Hasil Jawaban SKA dalam Menentukan

Perbandingan Trigonometri pada Segitiga Siku-siku
Hasil jawaban SKA, dapat dilihat bahwa SKA sudah mampu memahami cara menentukan konsep perbandingan trigonometri pada segitiga siku-siku. SKA sudah dapat menuliskan konsep sinus, cosinus, dan tangen dengan tepat, dan juga SKA dapat membedakan konsep perbandingan sinus, cosinus, dan tangen. Sehingga, SKA dapat menyimpulkan konsep perbandingan trigonometri pada segitiga siku-siku dengan tepat dan tanpa kesalahan. Berikut wawancara yang dilakukan dengan SKA :

- SKA-07 (P) : bagaimana tahapan kalian dalam menyelesaikan soal tersebut?

- SKA-07-6 (J) : tahapannya sudah jelas pada lembar kerja, dimana kami menentukan terlebih dahulu perbandingan sinus, cosinus dan tangen

- SKA-07-3 (J) : iya, karna sebelumnya kami sudah memahami konsep nya pada saat mengerjakan soal nommor 1

- SKA-09 (P) : bagaimana bentuk kesimpulan yang kalian peroleh dari soal?

- SKA-09-5 (J) : kesimpulannya bahwa untuk sinus merupakan perbandingan antara sisidepan/sisi miring $\angle B$, cosinusi perbandingan antara sisi samping/ sisi miring $\angle B$ dan tangen perbandingan antara sisi depan/ sisi samping $\angle B$. 


\begin{tabular}{|c|c|c|c|}
\hline $\begin{array}{c}\text { Tujuan } \\
\text { Pembelajaran } \\
\text { (learning goal) }\end{array}$ & $\begin{array}{c}\text { Aktivitas } \\
\text { Pembelajaran } \\
\text { (learning activity) }\end{array}$ & $\begin{array}{c}\text { Dugaan Alur Berpikir Peserta } \\
\text { Didik (hypothetical learning } \\
\text { process) }\end{array}$ & $\begin{array}{c}\text { Bantuan Guru (teacher } \\
\text { support) }\end{array}$ \\
\hline $\begin{array}{l}\text { Menentukan } \\
\text { perbandingan } \\
\text { trigonometri } \\
\text { pada segitiga } \\
\text { siku-siku }\end{array}$ & $\begin{array}{l}\text { Peserta didik } \\
\text { mengerjakan soal } \\
\text { mengenai } \\
\text { perbandingan } \\
\text { trigonometri pada } \\
\text { segitiga siku-siku. } \\
\text { Dalam hal ini soal } \\
\text { nomor } 2 \text {. }\end{array}$ & $\begin{array}{l}\text { Tipe } 1 \\
\text { Peserta didik dapat menentukan } \\
\text { konsep perbandingan } \sin , \cos \\
\text { dan tan dengan tepat dan } \\
\text { lengkap. }\end{array}$ & $\begin{array}{l}\text { Tipe } 1 \\
\text { Untuk jawaban peserta } \\
\text { didik tipe 1, guru tidak } \\
\text { perlu memberikan } \\
\text { bantuan karena peserta } \\
\text { didik sudah dapat } \\
\text { menyelesaikan soal } \\
\text { dengan baik. }\end{array}$ \\
\hline
\end{tabular}

\section{HLT SKA dalam Menentukan Perbandingan Trigonometri pada Segitiga Siku-siku}

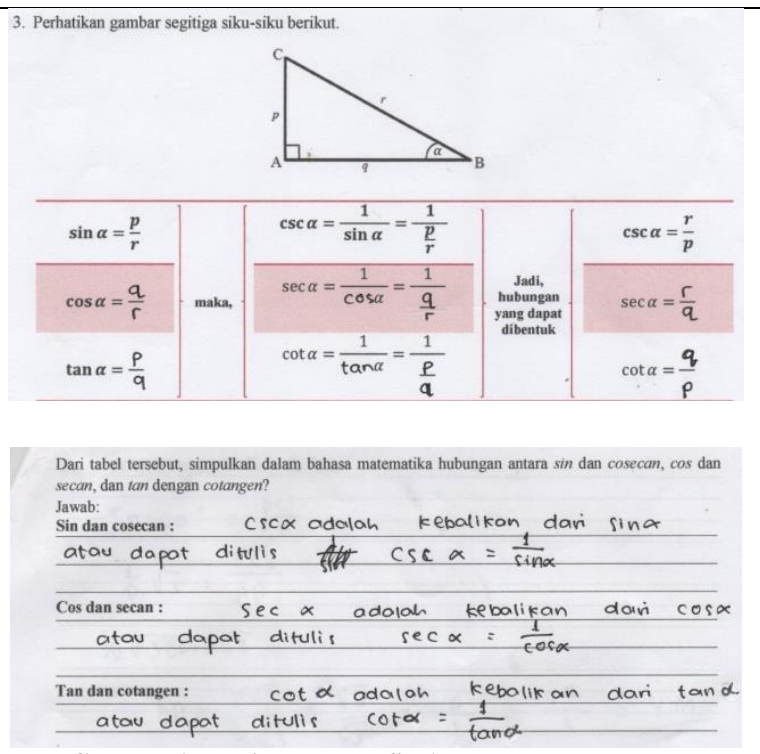

Gambar 3. Hasil Jawaban SKA dalam Menentukan Hubungan Antar Perbandingan Trigonometri pada Segitiga Siku-siku

A telah memahami hubungan antar perbandingan trigonometri pada segitiga siku-siku. SKA menuliskan jawaban pada tabel dengan benar, begitupun pada saat menarik kesimpulan dari hubungan antar perbandingan trigonometri pada segitiga siku-siku. SKA terlihat tidak mengalami kesulitan dan mampu menuliskan jawaban dengan tepat dan lengkap. Berikut wawancara yang dilakukan dengan SKA :

- SKA-12 (P) : bagaimana bentuk hubungan perbandingan yang kalian temukan pada soal?

- SKA-12-5 (J) : hubungan yang terbentuk itu merupakan perbandingan dari kebalikan perbandingan sinus, cosinus dan tangen.

- SKA-14 (P) : nah, bagaimana dengan kesimpulan dari table yang kalian kerjakan?

- SKA-14-2 (J) : kesimpulannya yaitu csc $\alpha$ adalah kebalikan dari $\sin \alpha$ atau dapat ditulis $\csc \alpha=\frac{1}{\sin \alpha}$, sec $\alpha$ adalah kebalikan dari $\cos \alpha$ atau dapat ditulis sec $\alpha=$ $\frac{1}{\cos \alpha}$ dan $\cot \alpha$ adalah kebalikan dari $\tan \alpha$ atau dapat ditulis $\cot \alpha=\frac{1}{\tan \alpha}$

\begin{tabular}{|c|c|c|c|}
\hline $\begin{array}{c}\text { Tujuan } \\
\text { Pembelajaran } \\
\text { (learning goal) }\end{array}$ & $\begin{array}{c}\text { Aktivitas } \\
\text { Pembelajaran } \\
\text { (learning activity) }\end{array}$ & $\begin{array}{c}\text { Dugaan Alur Berpikir Peserta } \\
\text { Didik (hypothetical learning } \\
\text { process) }\end{array}$ & $\begin{array}{c}\text { Bantuan Guru (teacher } \\
\text { support) }\end{array}$ \\
\hline $\begin{array}{l}\text { Menentukan } \\
\text { hubungan antar } \\
\text { perbandingan } \\
\text { trigonometri } \\
\text { pada segitiga } \\
\text { siku-siku }\end{array}$ & $\begin{array}{l}\text { Peserta didik } \\
\text { mengerjakan soal } \\
\text { mengenai hubungan } \\
\text { antar perbandingan } \\
\text { trigonometri. Dalam } \\
\text { hal ini soal nomor } 3 \text {. }\end{array}$ & $\begin{array}{l}\text { Tipe } 1 \\
\text { Peserta didik menuliskan } \\
\text { jawaban yang tepat dan lengkap } \\
\text { pada tabel. Sehingga, peserta } \\
\text { didik dapat menarik kesimpulan } \\
\text { dari hubungan antara sin dan } \\
\text { cosecan, cos dan secan, dan tan } \\
\text { dengan cotangen dengan jelas. }\end{array}$ & $\begin{array}{l}\text { Tipe } 1 \\
\text { Untuk jawaban peserta } \\
\text { didik tipe 1, guru tidak } \\
\text { perlu memberikan } \\
\text { bantuan karena peserta } \\
\text { didik sudah dapat } \\
\text { menyelesaikan soal } \\
\text { dengan baik. }\end{array}$ \\
\hline
\end{tabular}

HLT SKA dalam Menentukan Hubungan Antar Perbandingan Trigonometri pada Segitiga Siku-siku

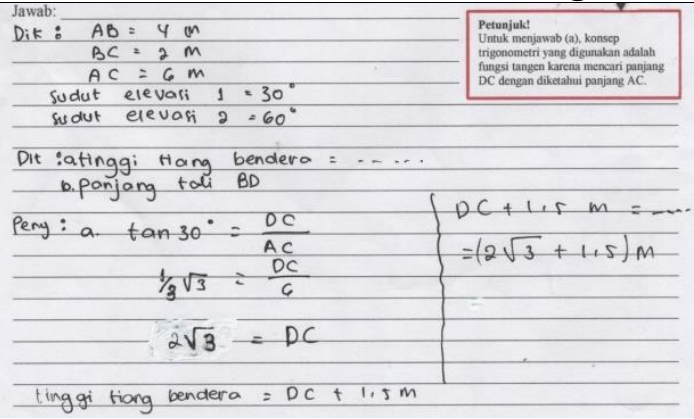

SKA telah memahami soal dan SKA dapat menuliskan yang diketahui dan yang ditanyakan dalam soal. Untuk bagian (a) peserta didik menggunakan perbandingan tan $30^{\circ}$, kemudian peserta didik menjumlahkan tinggi anak dan tinggi yang didapat untuk mendapatkan tinggi tiang sebenarnya, sedangkan pada bagian (b) peserta didik menggunakan cara yang sama seperti pada bagian (a) dengan konsep perbandingan yang digunakan yaitu perbandingan sin. Berikut wawancara yang dilakukan dengan SKA :

- SKA-15 (P) : bagaimana cara kalian menyelesaikan soal tersebut? 


\begin{tabular}{|c|c|c|c|c|c|}
\hline \multirow{2}{*}{\multicolumn{3}{|c|}{ b. panjang tali $B D$}} & & & \\
\hline \multirow{4}{*}{\multicolumn{3}{|c|}{$\begin{array}{l}\frac{\sin 60^{\circ}=\frac{D C}{B D}}{\frac{1}{2} \sqrt{3}=\frac{2 \sqrt{3}}{B D}}\end{array}$}} & & & \\
\hline & & & & & \\
\hline & & & & & \\
\hline & & & & & \\
\hline$\frac{1}{2} \sqrt{3} \bar{B} D=2 \sqrt{3}$ & & & & & \\
\hline \multicolumn{6}{|c|}{$B D=\frac{2 \sqrt{3}}{1 / 2 \sqrt{3}} \times \frac{\sqrt{3}}{\sqrt{3}}=\frac{6}{3 / 8}=\frac{12}{3}=4 \mathrm{~m}$} \\
\hline \multicolumn{6}{|c|}{$\begin{array}{l}\text { Gambar 4. Hasil Jawaban SKA dalam Menyelesaikan } \\
\text { Masalah Nyata yang Berkaitan dengan Perbandingan } \\
\text { Trigonometri pada Segitiga Siku-siku }\end{array}$} \\
\hline \multirow{4}{*}{\multicolumn{6}{|c|}{$\begin{array}{l}\text { - SKA-16-3 (J) : Kami memilih konsep perbandingan tangen, karena yang ditanyakan itu tinggi tiang (sisi } \\
\text { depan) atau DC + tinggi anak, nah yang di ketahui itu sisi AC atau sisi samping, sedangkan tangen itu } \\
\text { perbandingan antara sisi depan dan sisi samping, makanya kita bisa menggunakan konsep tangen untuk } \\
\text { menyelesaikan bagian (a). } \\
\text { - SKA-18 (P) : untuk bagian (b), bagaimana kalian bisa menggunakan cara yang sama seperti bagian (a)? } \\
\text { - SKA-18-5 (J) : karna, kalau dilihat pada bagian (a) maupun (b) sama-sama mencari satu bagian sisi yang tidak } \\
\text { diketahui, makanya kami menggunakan cara yang sama seperti bagian (a), dengan menggunakan konsep sin. } \\
\text { - SKA-19 (P) : terus mengapa kalian menggunakan konsep sinus? } \\
\text { - SKA-19-6 (J) : karena, konsep sinus bisa mencari sisi miring yang ditanyakan. Selain itu kita juga bisa } \\
\text { gunakan konsep cosinus, cosecan, dan secan. }\end{array}$}} \\
\hline & & & & & \\
\hline & & & & & \\
\hline & & & & & \\
\hline $\begin{array}{c}\text { Tujuan } \\
\text { Pembelajaran } \\
\text { (learning goal) }\end{array}$ & $\begin{array}{c}\text { Aktivitas } \\
\text { Pembelajaran } \\
\text { (learning activity) }\end{array}$ & & $\begin{array}{l}\text { gaan Alur Berpikir Peserta } \\
\text { dik (hypothetical learning } \\
\text { process) }\end{array}$ & $\begin{array}{l}\text { Bantuan Guru (teacher } \\
\text { support) }\end{array}$ & \\
\hline $\begin{array}{l}\text { Menyelesaikan } \\
\text { masalah nyata } \\
\text { yang berkaitan } \\
\text { dengan } \\
\text { perbandingan } \\
\text { trigonometri } \\
\text { pada segitiga } \\
\text { siku-siku }\end{array}$ & $\begin{array}{l}\text { Peserta didik } \\
\text { mengerjakan soal } \\
\text { terkait dengan } \\
\text { perbandingan } \\
\text { trigonometri pada } \\
\text { segitiga siku-siku.. } \\
\text { Dalam hal ini soal } \\
\text { nomor } 4 \text {. }\end{array}$ & & $\begin{array}{l}\text { 1 } \\
\text { sta didik dapat menentukan } \\
\text { nakan untuk menyelesaikan } \\
\text { an (a) dan bagian (b) } \\
\text { gan tepat dan lengkap. } \\
\text { in itu, peserta didik mampu } \\
\text { gaplikasikan konsep } \\
\text { but dengan baik. }\end{array}$ & $\begin{array}{l}\text { Tipe } 1 \\
\text { Untuk jawaban peserta } \\
\text { didik tipe 1, guru tidak } \\
\text { perlu memberikan } \\
\text { bantuan karena peserta } \\
\text { didik sudah dapat } \\
\text { menyelesaikan soal } \\
\text { dengan baik. }\end{array}$ & \\
\hline \multicolumn{6}{|c|}{$\begin{array}{c}\text { HLT SKA dalam Menyelesaikan Masalah Nyata yang Berkaitan dengan Perbandingan Trigonometri pada } \\
\text { Segitiga Siku-siku }\end{array}$} \\
\hline
\end{tabular}

Hasil jawaban SKS menunjukkan bahwa sudah dapat mengerjakan soal. Adapun alur berpikir SKS dalam mengerjakan soal nomor 1 tidak terdapat kesalahan, dan SKS telah mampu menuliskan jenis dari setiap perbandingan yang ditemukan. Untuk soal nomor 2 SKS masih sulit membedakan sudut yang digunakan untuk konsep perbandingan sinus, cosinus dan tangen. Jawaban SKS untuk nomor 3, sudah benar dan sesuai dengan jawaban yang sebenarnya sedangkan, untuk nomor 4 SKS masih mengalami kesalahan pada bagian (a) dimana hasil jawaban yang dituliskan tidak sesuai dengan yang diharapkan. Sejalan dengan penelitian Listiyana (Palayukan, 2018) menunjukkan kesulitan yang dihadapi peserta didik dalam menyelesaikan soal trigonometri yaitu kurang teliti dalam melakukan perhitungan yang berdampak pada penyelesaian masalah. 


\section{Berikut paparan hasil jawaban dan wawancara SKS :}

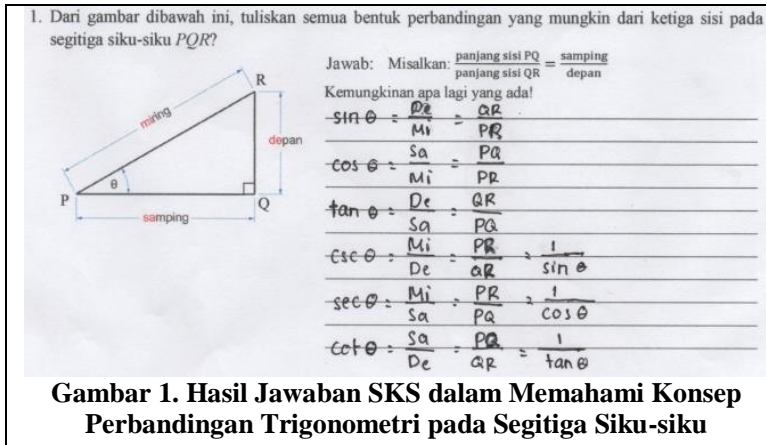

SKS sudah dapat menuliskan perbandingan trigonometri dengan benar, lengkap dan tidak terdapat kesalahan. Selain itu, SKS juga telah menuliskan jenis dari setiap perbandingan yang ditemukan dan bahkan sudah memahami hubungan dari perbandingan trigonometri yang belum ditanyakan. Berikut wawancara yang dilakukan dengan SKS :

- SKS-02 (P) : bagaimana tahapan kalian dalam menyelesaikan soal tersebut?

- SKS-02-2 (J) : pertama, kita lihat gambar segitiga $P Q R$, di mana soal meminta bentuk perbandingan yang mungkin terbentuk dari setiap sisi segitiga

- SKS-02-6 (J) : kami mendapat bahwa ada 6 bentuk perbandingan yang terbentuk dari segitiga $P Q R$

- SKS-04 (P) : Bagaimana menurut kalian, apakah masih terdapat konsep lain yang muncul, selain yang kalian jawabkan?

- SKS-04-4 (J) : tidak ada, karna cuman ada 6 perbandingan yang dapat terbentuk.

\begin{tabular}{|c|c|c|c|}
\hline $\begin{array}{c}\text { Tujuan } \\
\text { Pembelajaran } \\
\text { (learning goal) }\end{array}$ & $\begin{array}{c}\text { Aktivitas } \\
\text { Pembelajaran } \\
\text { (learning activity) }\end{array}$ & $\begin{array}{c}\text { Dugaan Alur Berpikir Peserta Didik } \\
\text { (hypothetical learning process) }\end{array}$ & $\begin{array}{c}\text { Bantuan Guru (teacher } \\
\text { support) }\end{array}$ \\
\hline $\begin{array}{l}\text { Memahami } \\
\text { konsep } \\
\text { perbandingan } \\
\text { trigonometri } \\
\text { pada segitiga } \\
\text { siku-siku }\end{array}$ & $\begin{array}{l}\text { Peserta didik } \\
\text { mengerjakan soal } \\
\text { mengenai konsep } \\
\text { perbandingan } \\
\text { trigonometri pada } \\
\text { segitiga siku-siku. } \\
\text { Dalam hal ini soal } \\
\text { nomor } 1 .\end{array}$ & $\begin{array}{l}\text { Tipe 1: } \\
\text { Peserta didik dapat menentukan } \\
\text { bentuk perbandingan yang mungkin } \\
\text { terbentuk pada segitiga siku-siku } \\
P Q R \text { dengan tepat dan lengkap. } \\
\text { Sehingga, peserta didik memahami } \\
\text { konsep perbandingan trigonometri } \\
\text { pada segitiga siku-siku. }\end{array}$ & $\begin{array}{l}\text { Tipe } 1 \\
\text { Untuk jawaban peserta } \\
\text { didik tipe 1, guru tidak } \\
\text { perlu memberikan } \\
\text { bantuan karena peserta } \\
\text { didik sudah dapat } \\
\text { menyelesaikan soal. }\end{array}$ \\
\hline
\end{tabular}

HLT SKS dalam Memahami Konsep Perbandingan Trigonometri

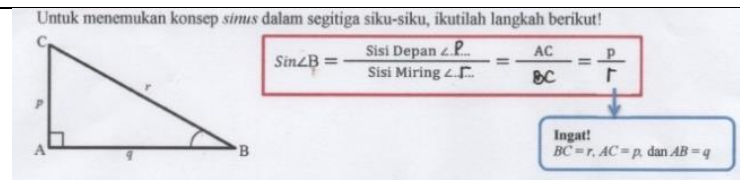

Berdasarkan keterangan di atas, maka yang dimaksud $\operatorname{Sin} \angle B$ adalah perbandingan antara Sisi depan sisi mlring

Untuk menemukan konsep cosimus dalam segitiga siku-siku, ikutilah langkah berikut

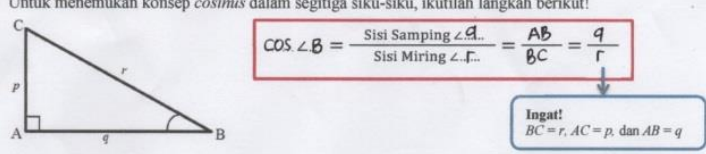

Berdasarkan keterangan di atas, maka yang dimaksud $\operatorname{Cos} \angle B$ adalah perbandingan antaro sisi samping dan sisi miring

Untuk menemukan konsep tangen dalam segitiga siku-siku, ikutilah langkah beriku!
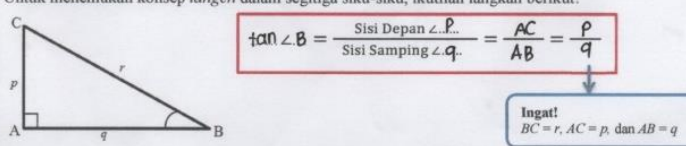

Berdasarkan keterangan di atas, maka yang dimaksud $\operatorname{Tan} \angle B$ adalah Perbandingan antara sisi depan dan sisi samping.

Gambar 2. Hasil Jawaban SKS dalam Menentukan Perbandingan Trigonometri pada Segitiga Siku-siku
Berdasarkan jawaban di samping, dapat dilihat bahwa SKS sudah mampu menentukan konsep perbandingan trigonometri pada segitiga siku-siku dan dapat menuliskan kesimpulan dengan baik. Namun, pada saat menuliskan nama sudut yang digunakan SKS masih mengalami kekeliruan, sehingga terjadi kesalahan, yang seharusnya peserta didik menuliskan sisi depan $\angle B$, sisi samping $\angle B$, dan sisi miring $\angle B$, peserta didik justru menuliskan sisi depan, sisi samping dan sisi miring dengan sudut yang bukan $\angle B$. Berikut wawancara yang dilakukan dengan SKS :

- SKS-06 (P) : bagaimana tahapan kalian dalam menyelesaikan soal?

- SKS-06-(J) : disini kami mengerjakan perbandingan sinus terlebih dahulu, terus perbandingan cosinus, dan kemudian perbandingan tangen, bersamaan dengan masing-masing kesimpulannya. 
- SKS-07 (P) : coba perhatikan, nama setiap sudut yang kalian tuliskan, apakah kalian tidak merasa ada yang salah dengan itu?

- SKS-07-1 (J) : kenapa kak?

- SKS-08 (P) : jadi, begini sebenarnya itu salah, intinya coba perhatikan bahwa sudut yang menjadi patokan kita yaitu $\angle B$, makanya pada konsep sinus itu terlebih dahulu dituliskan $\sin \angle B$. Jadi setiap sudut segitiga yang terdapat pada konsep $\sin$, cos dan tan kita namakan $\angle B$ karena $\angle B$ adalah patokan kita untuk mencari perbandingan sinus, cosinus dan tangen.

- SKS-08-2 (J) : oh begitu, jadi untuk perbandingan sinus, cosinus dan tangen semua nama sudutnya diganti dengan $\angle B$, selebihnya sudah benar?

- SKS-10 (P) : jadi, bagaimana kesimpulan yang kalian peroleh dari soal?

- SKS-10-4 (J) : kesimpulannya yaitu perbandingan sinus merupakan perbandingan antara sisi depan / sisi miring, perbandingan cosinus merupakan perbandingan antara samping/ miring, dan yang terakhir perbandingan tangen merupakan perbandingan antara depan/ samping.

\begin{tabular}{|c|c|c|c|}
\hline $\begin{array}{c}\text { Tujuan } \\
\text { Pembelajaran } \\
\text { (learning goal) }\end{array}$ & $\begin{array}{c}\text { Aktivitas } \\
\text { Pembelajaran } \\
\text { (learning activity) }\end{array}$ & $\begin{array}{l}\text { Dugaan Alur Berpikir Peserta Didik } \\
\text { (hypothetical learning process) }\end{array}$ & $\begin{array}{c}\text { Bantuan Guru (teacher } \\
\text { support) }\end{array}$ \\
\hline $\begin{array}{l}\text { Menentukan } \\
\text { perbandingan } \\
\text { trigonometri } \\
\text { pada segitiga } \\
\text { siku-siku }\end{array}$ & $\begin{array}{l}\text { Peserta didik } \\
\text { mengerjakan soal } \\
\text { mengenai } \\
\text { perbandingan } \\
\text { trigonometri pada } \\
\text { segitiga siku-siku. } \\
\text { Dalam hal ini soal } \\
\text { nomor } 2 \text {. }\end{array}$ & $\begin{array}{l}\text { Tipe } 2 \\
\text { Peserta didik dapat menentukan } \\
\text { konsep perbandingan sin, cos dan } \\
\text { tan. Namun, masih terdapat } \\
\text { kekeliruan dalam menuliskan nama } \\
\text { sudut yang digunakan. }\end{array}$ & $\begin{array}{l}\text { Tipe } 2 \\
\text { Untuk jawaban peserta } \\
\text { didik tipe 2, guru perlu } \\
\text { memberikan bantuan } \\
\text { karena peserta didik } \\
\text { masih belum paham } \\
\text { dengan sudut yang } \\
\text { digunakan. }\end{array}$ \\
\hline
\end{tabular}

\section{HLT SKS dalam Menentukan Perbandingan Trigonometri pada Segitiga Siku-siku}

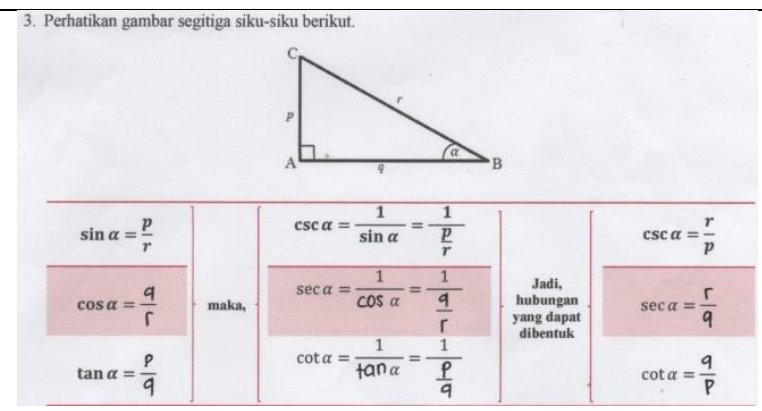

Dari tabel tersebut, simpulkan dalam bahasa matematika hubungan antara $\sin$ dan $\operatorname{cosecan}$, cos dan secan, dan tan dengan cotangen?

secan, d
Jawab:
Sin dan

Sin dan cosecan : cosecan merupakan kebalikan dari sin sehingga $\csc \alpha$ sama dengan 1

$$
\frac{1}{\sin \alpha}
$$

Cos dan secan : secan merupakan kebalikan dari cos, sehingga sec $\alpha$ sama dengan 1

$\frac{1}{\cos \alpha}$

SKS menuliskan jawaban pada tabel dengan benar dan tepat, kemudian peserta didik juga mampu menyimpulkan hubungan perbandingan trigonometri pada segitiga siku-siku. Untuk soal nomor 3 SKA terlihat sudah memahami mengenai hubungan antar perbandingan trigonometri, ini sesuai dengan pada saat SKS mengerjakan soal nomor 1. Berikut wawancara yang dilakukan dengan SKS :

- SKS-12 (P) : bagaimana bentuk hubungan perbandingan yang kalian temukan pada table?

- SKS-12-1 (J) : hubungan yang terbentuk itu, dimana sinus memiliki hubungan dengan cosecant, cosinus dengan secan, kemudian tangen memiliki hubungan dengan cotangent.

- SKS-14 (P) : jadi, bagaimana kesimpulan yang kalian peroleh dari soal?

- SKS-14-4 (J) : dari tabel tersebut, kami menyimpulkan bahwa cosecan merupakan kebalikan dari sin sehingga sama dengan

$$
\frac{1}{\tan \alpha}
$$

Gambar 3. Hasil Jawaban SKS dalam Menentukan Hubungan Antar Perbandingan Trigonometri pada Segitiga Siku-siku $\csc \alpha=\frac{1}{\sin \alpha}$, secan merupakan kebalikan dari cos sehingga $\sec \alpha=\frac{1}{\cos \alpha}$ dan cotangen merupakan

\begin{tabular}{|c|c|c|c|}
\hline $\begin{array}{c}\text { Tujuan } \\
\text { Pembelajaran } \\
\text { (learning goal) }\end{array}$ & $\begin{array}{c}\text { Aktivitas } \\
\text { Pembelajaran } \\
\text { (learning activity) }\end{array}$ & $\begin{array}{l}\text { Dugaan Alur Berpikir Peserta Didik } \\
\text { (hypothetical learning process) }\end{array}$ & $\begin{array}{c}\text { Bantuan Guru (teacher } \\
\text { support) }\end{array}$ \\
\hline $\begin{array}{l}\text { Menentukan } \\
\text { hubungan antar } \\
\text { perbandingan } \\
\text { trigonometri } \\
\text { pada segitiga } \\
\text { siku-siku }\end{array}$ & $\begin{array}{l}\text { Peserta didik } \\
\text { mengerjakan soal } \\
\text { mengenai } \\
\text { hubungan antar } \\
\text { perbandingan } \\
\text { trigonometri. } \\
\text { Dalam hal ini soal } \\
\text { nomor } 3 \text {. }\end{array}$ & $\begin{array}{l}\text { Tipe } 1 \\
\text { Peserta didik menuliskan jawaban } \\
\text { yang tepat dan lengkap pada tabel. } \\
\text { Sehingga, peserta didik dapat } \\
\text { menarik kesimpulan dari hubungan } \\
\text { antara sin dan cosecan, cos dan } \\
\text { secan, dan tan dengan cotangen. }\end{array}$ & $\begin{array}{l}\text { Tipe } 1 \\
\text { Untuk jawaban peserta } \\
\text { didik tipe 1, guru tidak } \\
\text { perlu memberikan } \\
\text { bantuan karena peserta } \\
\text { didik sudah dapat } \\
\text { menyelesaikan soal } \\
\text { dengan baik. }\end{array}$ \\
\hline
\end{tabular}
kebalikan dari tan sehingga $\cot \alpha=\frac{1}{\tan \alpha}$ 
HLT SKS dalam Menentukan Hubungan Antar Perbandingan Trigonometri pada Segitiga Siku-siku

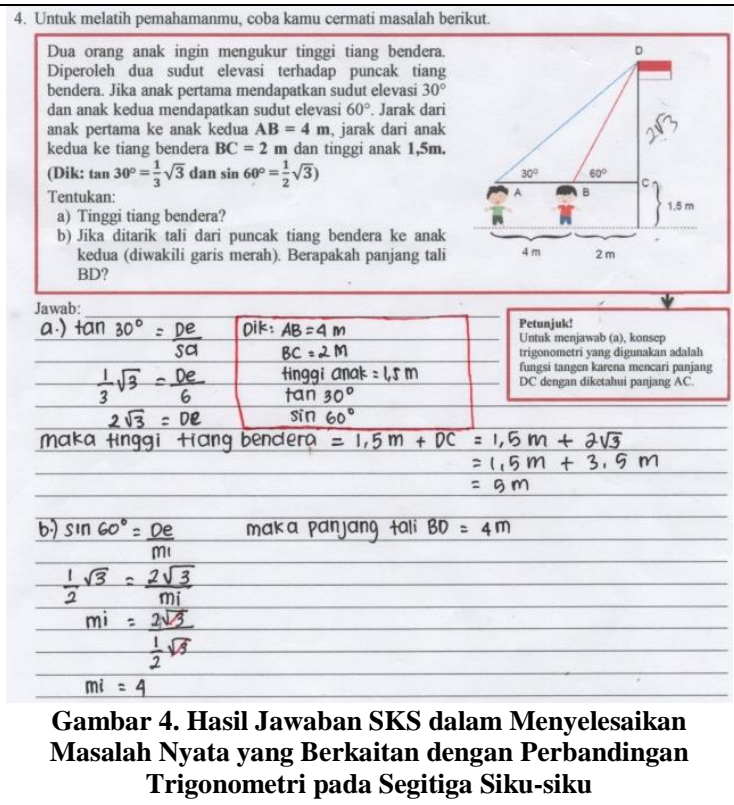

Jawaban yang ditunjukkan SKS masih terdapat kesalahan pada bagian (a) saat menjumlahkan tinggi sebenarnya tiang bendera, di mana SKS menuliskan hasil yang tidak sesuai dengan jawaban yang sebenarnya. SKS bisa tidak mencari hasil dari $2 \sqrt{3}$ dan bisa langsung menuliskan jawaban $(1,5+2 \sqrt{3}) \mathrm{m}$, agar sesuai dengan jawaban yang diharapkan, sedangkan pada bagian (b) jawaban SKS sudah sesuai dan keseluruhan langkahlangkah pengerjaannya juga sudah benar dan tepat. Berikut wawancara yang dilakukan dengan SKS :

- SKS-15 (P) : bagaimana cara kalian menyelesaikan soal tersebut?

- SKS-15-3 (J) : pertama itu, kita menulis yang diketahui dan tanyakan kemudian menjawab bagian (a) dan bagian (b)

- SKS-15-6 (J) : untuk bagian (a) kami menggunakan konsep perbandingan tangen karena pada bagian (a) yang ditanyakan itu sisi depannya dan yang di ketahui itu sisi samping.

- SKS-16 (P) : nah, apakah ada konsep lain yang bisa digunakan untuk menyelesaikan bagian (a)?

- SKS-16-5 (J) : iya ada, yaitu kita bisa gunakan perbandingan cotangen, selain itu kita tidak bisa menggunakan konsep perbandingan lainnya.

- SKS-18 (P) : jadi begini, untuk $2 \sqrt{3}$ itu bisa tidak disederhanakan, dan hasilnya bisa langsung dijumlahkan saja menjadi $(1,5+2 \sqrt{3}) \mathrm{m}$, karena nilainya memiliki satuan yang sama.

- SKS-19 (P) : selanjutnya, untuk bagian (b) kalian menggunakan cara yang sama seperti pada bagian (a), mengapa demikian?

- SKS-19-2 (J) : sebenarnya itu, kami ingin menggunakan phytagoras, karena pada bagian (b) itu mencari sisi miring, nah disini kami kan lagi belajar mengenai perbandingan trigonometri jadi makanya kami gunakan konsep perbandingan untuk selesaikan bagian (b)

- SKS-19-4 (J) : Iya, nah caranya itu sama seperti pada bagian (a), namun disini kami menggunakan konsep sin, karena di soal itu yang dicari sisi miring dan yang diketahui adalah sisi depan

\begin{tabular}{|c|c|c|c|}
\hline $\begin{array}{c}\text { Tujuan } \\
\text { Pembelajaran } \\
\text { (learning goal) }\end{array}$ & $\begin{array}{c}\text { Aktivitas } \\
\text { Pembelajaran } \\
\text { (learning activity) }\end{array}$ & $\begin{array}{l}\text { Dugaan Alur Berpikir Peserta Didik } \\
\text { (hypothetical learning process) }\end{array}$ & $\begin{array}{c}\text { Bantuan Guru (teacher } \\
\text { support) }\end{array}$ \\
\hline $\begin{array}{l}\text { Menyelesaikan } \\
\text { masalah nyata } \\
\text { yang berkaitan } \\
\text { dengan } \\
\text { perbandingan } \\
\text { trigonometri } \\
\text { pada segitiga } \\
\text { siku-siku }\end{array}$ & $\begin{array}{l}\text { Peserta didik } \\
\text { mengerjakan soal } \\
\text { terkait dengan } \\
\text { perbandingan } \\
\text { trigonometri pada } \\
\text { segitiga siku- } \\
\text { siku.. Dalam hal } \\
\text { ini soal nomor } 4 \text {. }\end{array}$ & $\begin{array}{l}\text { Tipe } 2 \\
\text { Peserta didik dapat menentukan } \\
\text { konsep perbandingan yang } \\
\text { digunakan untuk menyelesaikan } \\
\text { bagian (a) dan bagian (b). Namun, } \\
\text { untuk bagian (a) masih terdapat } \\
\text { sedikit kesalahan yaitu pada saat } \\
\text { menjumlahkan tinggi tiang } \\
\text { sebenamya. }\end{array}$ & $\begin{array}{l}\text { Tipe } 2 \\
\text { Untuk jawaban peserta } \\
\text { didik tipe } 2 \text {, guru hanya } \\
\text { perlu memberikan sedikit } \\
\text { bantuan pada saat } \\
\text { menjumlahkan tinggi } \\
\text { tiang sebenamya. }\end{array}$ \\
\hline
\end{tabular}

HLT SKS dalam Menyelesaikan Masalah Nyata yang Berkaitan dengan Perbandingan Trigonometri pada Segitiga Siku-siku

Tidak seperti SKA dan SKS, SKTA justru lebih banyak mengalami kesalahan pada saat mengerjakan soal. Jawaban SKTA untuk nomor 1, 2 dan 4, masih terdapat kesalahan dimana, untuk nomor 1 belum dapat menuliskan perbandingan trigonometri yang sesuai, begitupun pada nomor 2, SKTA masih keliru dengan penggunaan sudut untuk konsep sinus, cosinus dan tangen, 
sedangkan pada nomor 4 SKTA tidak menyelesaikan soal sampai selesai. Namun,

untuk nomor 3 SKTA sudah bisa menyelesaikan soal dan tanpa kesalahan.

\section{Berikut paparan hasil jawaban dan wawancara SKTA :}

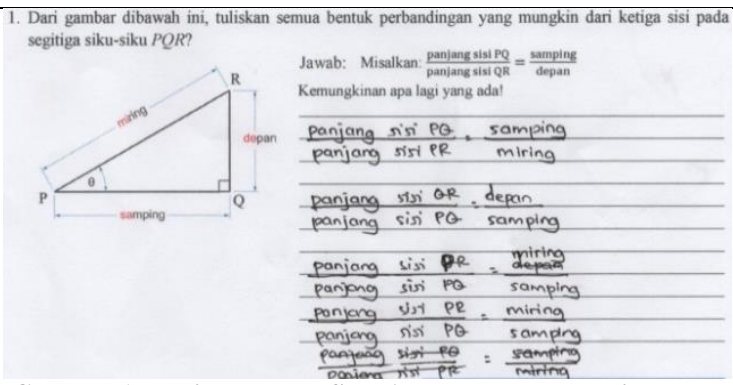

Gambar 1. Hasil Jawaban SKTA dalam Memahami Konsep Perbandingan Trigonometri pada Segitiga Siku-siku
SKTA masih belum menuliskan semua perbandingan yang dapat terbentuk, dan hanya mampu menuliskan 4 perbandingan dari segitiga siku-siku $P Q R$ Sehingga, pada lembar jawaban SKTA terdapat beberapa coretan, tampaknya SKTA masih kurang yakin dengan jawaban yang dituliskan, dan ada juga jawaban yang sama dituliskan kembali. Berikut wawancara yang dilakukan dengan SKTA :

- SKTA-02 (P) : bagaimana tahapan kalian dalam menyelesaikan soal tersebut?

- SKTA-02-1 (J) : disini kami, menuliskan perbandingan yang kami temukan dari segitiga siku-siku $P Q R$

- SKTA-02-4 (J) : nah, yang kami temukan hanya 4, karna menurut kami hanya itu yang dapat terbentuk

- SKTA-03 (P) : nah, disini coba kalian perhatikan, kalian menuliskan 2 perbandingan yang sama secara berulang, jadi total keseluruhan kalian menuliskan perbandingan yang benar cuman 3, ditambah dengan contoh jadi 4, kalian kurang menuliskan 2 perbandingan lainnya yaitu $\frac{Q R}{R P} \operatorname{dan} \frac{R P}{Q R}$.

- SKTA-04 (P) : dari penjelasan tadi, apakah kalian sudah paham?

- SKTA-04-6 (J) : sudah paham kak, karna sudah kita jelaskan.

\begin{tabular}{|c|c|c|c|}
\hline $\begin{array}{c}\text { Tujuan } \\
\text { Pembelajaran } \\
\text { (learning goal) }\end{array}$ & $\begin{array}{c}\text { Aktivitas } \\
\text { Pembelajaran } \\
\text { (learning activity) }\end{array}$ & $\begin{array}{l}\text { Dugaan Alur Berpikir Peserta Didik } \\
\text { (hypothetical learning process) }\end{array}$ & $\begin{array}{l}\text { Bantuan Guru (teacher } \\
\text { support) }\end{array}$ \\
\hline $\begin{array}{l}\text { Memahami } \\
\text { konsep } \\
\text { perbandingan } \\
\text { trigonometri } \\
\text { pada segitiga } \\
\text { siku-siku }\end{array}$ & $\begin{array}{l}\text { Peserta didik } \\
\text { mengerjakan soal } \\
\text { mengenai konsep } \\
\text { perbandingan } \\
\text { trigonometri pada } \\
\text { segitiga siku-siku. } \\
\text { Dalam hal ini soal } \\
\text { nomor } 1 \text {. }\end{array}$ & $\begin{array}{l}\text { Tipe } 3 \\
\text { Peserta didik masih kurang } \\
\text { memahami konsep perbandingan } \\
\text { trigonometri. Sehingga, peserta } \\
\text { didik tidak dapat menuliskan semua } \\
\text { bentuk perbandingan yang mungkin } \\
\text { dari segitiga siku-siku } P Q R \text { dan } \\
\text { peserta didik belum mengetahui } \\
\text { jenis perbandingan yang ditemukan. }\end{array}$ & $\begin{array}{l}\text { Tipe } 3 \\
\text { Untuk jawaban peserta } \\
\text { didik tipe } 3 \text {, guru perlu } \\
\text { memberikan bantuan agar } \\
\text { peserta didik bisa } \\
\text { menuliskan perbandingan } \\
\text { yang masih kurang } \\
\text { dengan benar. }\end{array}$ \\
\hline
\end{tabular}

\section{HLT SKTA dalam Memahami Konsep Perbandingan Trigonometri}

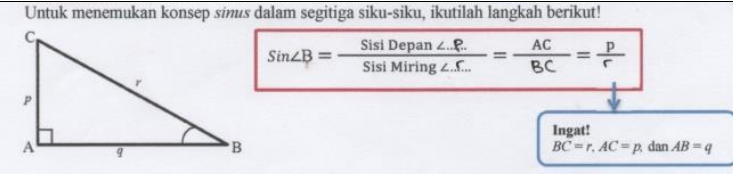

Berdasarkan keterangan di atas, maka yang dimaksud $\operatorname{Sin} \angle B$ adalah _perbondingon antara sisi depen dan sisi miring

Untuk menemukan konsep cosimus dalam segitiga siku-siku, ikutilah langkah berikut!
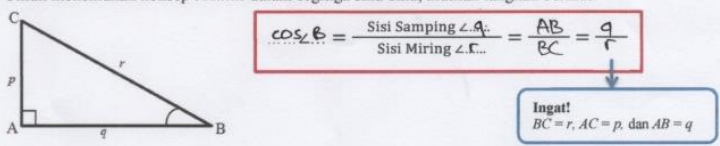

Berdasarkan keterangan di atas, maka yang dimaksud $\operatorname{Cos} \angle B$ adalah perbondingon ontaro sisi samping don nis miring

Untuk menemukan konsep tangen dalam segitiga siku-siku, ikutilah langkah beriku!
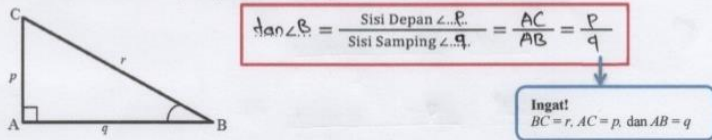

Berdasarkan keterangan di atas, maka yang dimaksud $\operatorname{Tan} \angle B$ adalah perbondingon ontora sist depon don sisi samping

Gambar 2. Hasil Jawaban SKTA dalam Menentukan

Perbandingan Trigonometri pada Segitiga Siku-siku

SKTA-09-5 (J) : tidak tau juga kak, karena dikira sisi yang di depan itu AC atau P makanya begitu ditulis
Jawaban SKTA pada nomor 2 ini sudah jelas, namun masih terdapat kesalahan dalam menuliskan nama sudut yang digunakan. SKTA tidak konsisten dalam menuliskan nama setiap sudut, seperti $\tan \angle B$ adalah perbandingan antara sisi depan $\angle B$ dan sisi samping $\angle B$, SKTA justru menuliskan sisi depan $\angle P$ dan sisi samping $\angle Q$. Oleh karena itu, SKTA masih bingung dalam menentukan sudut yang sebenarnya digunakan. Berikut wawancara yang dilakukan dengan SKTA :

- SKTA-07 (P) : bagaimana tahapan kalian dalam menyelesaikan soal?

- SKTA-07-1 (J) : kami menemukan konsep sinus terlebih dahulu, lalu perbandingan cosinus, dan perbandingan tangen, dan tidak lupa kesimpulan setiap perbandingan

- SKTA-09 (P) : coba lihat jawaban yang kalian tuliskan, disini mengapa kalian menuliskan nama setiap sudut dengan nama sisi-sisi segitiga? 
- SKTA-10 (P) : begini, bedakan antara nama sudut dan nama sisi, disitu jelas dibilang sisi depan sudut, nah dalam segitiga $\mathrm{ABC}$ hanya ada 3 nama sudut diantaranya $\angle A, \angle B$, dan $\angle C$. Kalian perhatikan di soal disitu sudah ada petunjuk pada konsep $\sin$ bahwa kita menggunakan $\angle B$ sebagai patokan, makanya tertulis $\sin \angle B$, begitupun untuk perbandingan lainnya. Paham semuaji?

- SKTA-10 (J) : paham kak

\begin{tabular}{|c|c|c|c|}
\hline $\begin{array}{c}\text { Tujuan } \\
\text { Pembelajaran } \\
\text { (learning goal) }\end{array}$ & $\begin{array}{c}\text { Aktivitas } \\
\text { Pembelajaran } \\
\text { (learning activity) }\end{array}$ & $\begin{array}{l}\text { Dugaan Alur Berpikir Peserta Didik } \\
\text { (hypothetical learning process) }\end{array}$ & $\begin{array}{c}\text { Bantuan Guru (teacher } \\
\text { support) }\end{array}$ \\
\hline $\begin{array}{l}\text { Menentukan } \\
\text { perbandingan } \\
\text { trigonometri } \\
\text { pada segitiga } \\
\text { siku-siku }\end{array}$ & $\begin{array}{l}\text { Peserta didik } \\
\text { mengerjakan soal } \\
\text { mengenai } \\
\text { perbandingan } \\
\text { trigonometri pada } \\
\text { segitiga siku-siku. } \\
\text { Dalam hal ini soal } \\
\text { nomor } 2 \text {. }\end{array}$ & $\begin{array}{l}\text { Tipe } 2 \\
\text { Peserta didik dapat menentukan } \\
\text { konsep perbandingan sin, cos dan } \\
\text { tan. Namun, masih terdapat } \\
\text { kekeliruan dalam menuliskan nama } \\
\text { sudut yang digunakan. }\end{array}$ & $\begin{array}{l}\text { Tipe } 2 \\
\text { Untuk jawaban peserta } \\
\text { didik tipe 2, guru perlu } \\
\text { memberikan bantuan } \\
\text { karena peserta didik } \\
\text { masih belum paham } \\
\text { dengan sudut yang } \\
\text { digunakan. }\end{array}$ \\
\hline
\end{tabular}

\section{HLT SKTA dalam Menentukan Perbandingan Trigonometri pada Segitiga Siku-siku}

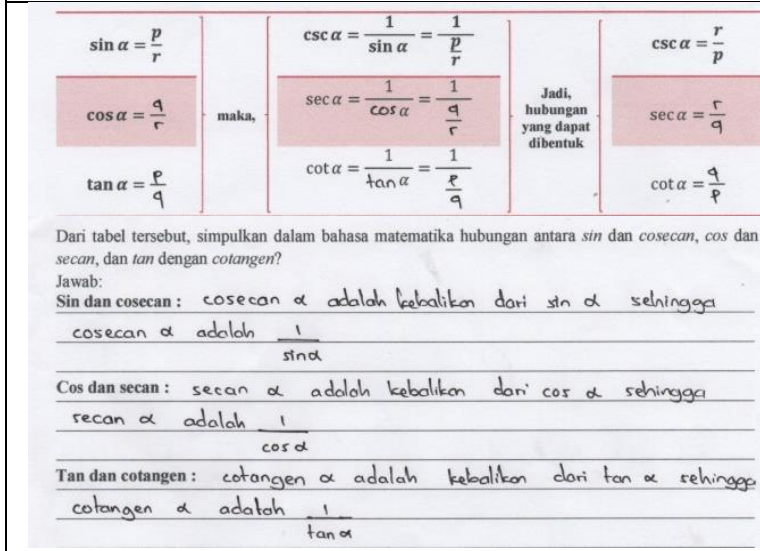

Gambar 3. Hasil Jawaban SKTA dalam Menentukan Hubungan Antar Perbandingan Trigonometri pada Segitiga Siku-siku

SKTA sudah menuliskan jawaban pada tabel dengan benar sesuai dengan jawaban yang sebenarnya, dan SKTA dapat menyimpulkan hubungan perbandingan trigonometri pada segitiga siku-siku. Jawaban SKTA jika dianalisis pada komponen dugaan alur berpikir peserta didik HLT yaitu tipe 1. Adapun pada komponen bantuan guru (teacher support) guru tidak perlu memberikan bantuan pada SKTA. Berikut wawancara yang dilakukan dengan SKTA :

- SKTA-13 (P) : bagaimana urutan langkah-langkah kalian dalam menyelesaikan soal?

- SKTA-13-1 (J) : disini kami, mengisi tabelnya dulu, lalu kemudian memberikan kesimpulan terkait hubungan perbandingan sesuai dengan table

- SKTA-14 (P) : nah, bagaimana bentuk hubungan perbandingan yang kalian temukan?

- SKTA-14-2 (J) : kami menemukan bahwa hubungan yang dapat terbentuk dari perbandingan sebelumnya yaitu, perbandingan sin memiliki hubungan dengan cosecan, perbandingan cos memiliki hubungan dengan secan dan perbandingan tangen memiliki hubungan dengan cotangen.

\begin{tabular}{|c|c|c|c|}
\hline $\begin{array}{c}\text { Tujuan } \\
\text { Pembelajaran } \\
\text { (learning goal) }\end{array}$ & $\begin{array}{c}\text { Aktivitas } \\
\text { Pembelajaran } \\
\text { (learning activity) }\end{array}$ & $\begin{array}{l}\text { Dugaan Alur Berpikir Peserta Didik } \\
\text { (hypothetical learning process) }\end{array}$ & $\begin{array}{c}\text { Bantuan Guru (teacher } \\
\text { support) }\end{array}$ \\
\hline $\begin{array}{l}\text { Menentukan } \\
\text { hubungan antar } \\
\text { perbandingan } \\
\text { trigonometri } \\
\text { pada segitiga } \\
\text { siku-siku }\end{array}$ & $\begin{array}{l}\text { Peserta didik } \\
\text { mengerjakan soal } \\
\text { mengenai } \\
\text { hubungan antar } \\
\text { perbandingan } \\
\text { trigonometri. } \\
\text { Dalam hal ini soal } \\
\text { nomor } 3 \text {. }\end{array}$ & $\begin{array}{l}\text { Tipe } 1 \\
\text { Peserta didik menuliskan jawaban } \\
\text { yang tepat dan lengkap pada tabel. } \\
\text { Sehingga, peserta didik dapat } \\
\text { menarik kesimpulan dari hubungan } \\
\text { antara sin dan cosecan, cos dan } \\
\text { secan, dan tan dengan cotangen } \\
\text { dengan jelas. }\end{array}$ & $\begin{array}{l}\text { Tipe } 1 \\
\text { Untuk jawaban peserta } \\
\text { didik tipe 1, guru tidak } \\
\text { perlu memberikan } \\
\text { bantuan karena peserta } \\
\text { didik sudah dapat } \\
\text { menyelesaikan soal } \\
\text { dengan baik. }\end{array}$ \\
\hline
\end{tabular}

HLT SKTA dalam Menentukan Hubungan Antar Perbandingan Trigonometri pada Segitiga Siku-siku 


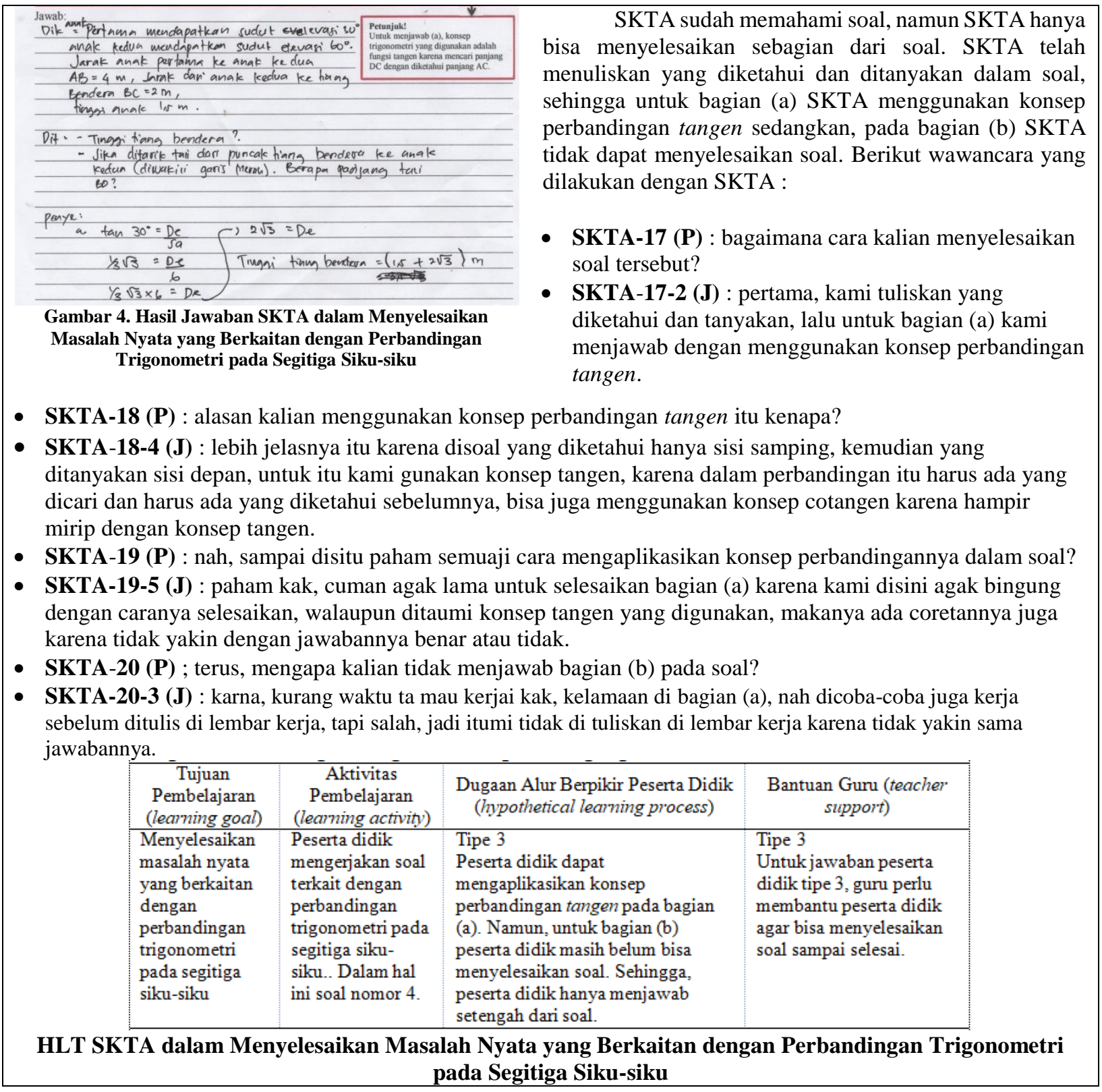

Berdasarkan penjelasan yang telah dipaparkan, dapat disimpulkan bahwa model pembelajaran kooperatif tipe group investigation dapat digunakan untuk melihat HLT peserta didik dan alur berpikir peserta didik kelas X IPA 1 menunjukkan bahwa HLT yang diperoleh peserta didik tidak jauh berbeda dengan HLT yang telah dirancang oleh peneliti dan dari penjelasan di atas juga diketahui bahwa setiap peserta didik memiliki alur yang berbeda-beda dalam memahami maupun menyelesaikan soal. Seperti pada hasil penelitian Sholihah (2018) menunjukkan bahwa alur berpikir peserta didik berkemampuan akademis tinggi, sedang dan rendah memiliki alur yang berbeda-beda dalam menyelesaikan soal mengenai himpunan. Selain itu, pada penelitian ini guru telah memberikan bantuan 
(teacher support) sesuai dengan alur berpikir yang dimiliki peserta didik khususnya pada konsep perbandingan trigonometri, dimana setelah diberikan bantuan peserta didik sudah dapat memahami konsep perbandingan trigonometri. Sejalan dengan hasil penelitian Ayunika (Ramadhanti, 2015) menunjukkan dengan bantuan HLT dapat membangun pemahaman peserta didik terhadap konsep-konsep matematis dan penelitian Ramadhanti (2015) menunjukkan bahwa penggunaan HLT dapat mengetahui lintasan belajar peserta didik dalam memahami konsep elastisitas.

\section{Kesimpulan}

Berdasarkan hasil analisis dan pembahasan yang telah dilakukan, maka dalam penelitian ini dapat disimpulkan bahwa hypothetical learning trajectory (HLT) peserta didik kelas X SMA Negeri 2 Palopo tidak jauh berbeda dengan HLT yang dibuat oleh peneliti.

1. Alur berpikir subjek kelompok aktif (SKA) pada materi trigonometri menunjukkan peserta didik dapat memahami dan mengerjakan soal sesuai dengan prosedur pengerjaan soal. Hasil HLT juga menunjukkan SKA berada pada tipe 1 untuk soal nomor 2, 3 dan 4, sedangkan untuk nomor 1 SKA berada pada tipe 2 .

2. Alur berpikir subjek kelompok sedang (SKS) pada materi trigonometri menunjukkan peserta didik dapat memahami dan mengerjakan soal walaupun masih terdapat kesalahan. Hasil HLT menunjukkan SKS untuk nomor 1 dan 3 berada pada tipe 1 sedangkan, untuk nomor 2 dan 4 berada pada tipe 2 .

3. Alur berpikir subjek kelompok tidak aktif (SKTA) pada materi trigonometri menunjukkan peserta didik dapat menyelesaikan soal walaupun masih terdapat banyak kesalahan pada hasil jawabannya. Hasil HLT menunjukkan SKTA masih bermasalah pada nomor 1 dan 4 sesuai dengan tipe yang diperoleh yaitu tipe 3, sedangkan untuk nomor 2 juga masih terdapat kesalahan sehingga SKTA berada pada tipe 2, dan untuk nomor 3 sudah bisa mengerjakan soal sehingga SKTA berada pada tipe 1 .

\section{Daftar Pustaka}


Fuadiah, N. F. 2017. Hypothetical Learning Trajectory pada Pembelajaran Bilangan Negatif Berdasarkan Teori Situasi Didaktis di Sekolah Menengah. Jurnal Mosharafa, Vol. 6, No.1.

Mhuzdaliva, R. A. 2016. Analisis Kesalahan Peserta Didik dalam Menyelesaikan Soal Trigonometri dengan Panduan Kriteria Polya Kelas XI SMA Negeri 1 Segeri Kabupaten Pangkep. Skripsi diterbitkan (Online). Makassar: UIN Alauddin Makassar.

Nikmaturrohmah, D. 2018. Analisis learning trajectory siswa dalam memecahkan masalah matematika ditinjau dari gaya belajar. Diss. UIN Sunan Ampel Surabaya.

Palayukan, H. 2018. Analisis Kesalahan Siswa Dalam Menyelesaikan Soal Perbandingan Trigonometri Pada Segitiga Siku-Siku Berdasarkan Kriteria Watson Di Kelas X Sma Katolik Rantepao. Inspiramatika, 4(1), 47-60.

Ramadhanti, P. 2015. Penggunaan Hypothetical Learning Trajectory (HLT) pada materi elastisitas untuk mengetahui lintasan belajar siswa kelas X Di SMA Negeri 1 Indralaya Utara. Jurnal Inovasi Dan Pembelajaran Fisika, 2(1), 88-98.

Ratnasari, F. 2018. Pengembangan Perangkat Pembelajaran Trigonometri Berbasis Penemuan Terbimbing dengan Pendekatan Saintifik Berorientasi pada Prestasi Belajar, Kemampuan Berpikir Kritis, dan Kepercayaan Diri Siswa Kelas X. S2 thesis, UNY.

Sholihah, L. H. 2018. Analisis Hipotesis Lintasan Belajar (Hypothetical Learning Trajectory) Dan Pemahaman Konsep Siswa Pada Materi Himpunan Kelas VII MTsN Gandusari Tahun Ajaran 2017/2018.

Wuriyudani, H. A. 2015. Implementasi Strategi Pembelajaran Fisika Berbasis Hypothetical Learning Trajectory (HLT) Untuk Meningkatkan Keterampilan Berpikir Ilmiah Siswa. Diss. Universitas Negeri Semarang. 